\section{Весна Крстевска}

$\mathrm{KoH}$ Women in Greek Myth, Mary R. Lefkowitz; London: Bristol Classical Press, 1995.

O ваа импресивна студија на професорката Лефковиц претставува обид да се опише на кој начин Грците го портретирале женското искуство во митовите и да се претстават некои негови аспекти кои најчесто биле поинаку толкувани. Користејки компаративен метод, таа ги споредува митовите со други грчки и римски текстови, со цел да се доближи повеќе до изворниот јазик на оригиналниот текст и избегнува да тргнува од позиција на структуралната антропологија и за едно комллексно прашање да зборува преку бинарни опозиции. Авторката нема амбиција да ја намени книгата само за специјализирани читатели, таа може да му се додвори и на обичниот читател со едноставниот но аналитичен стил, без претензии за теориска систематизација.

Лефковиц во оваа студија ги прикажува женските карактери во митовите, литературата, историската документација и се концентрира на оние аспекти од женското искуство кои најчесто се погрешно разбрани - животот на жените кои се одвоени од мажите, бракот, улогата на жената во политиката, самопожртвуваноста и мачеништвото и природата на мисогинијата.

Обидувајќи се да ја разгатне родовата позиционираност во приказната на грчката цивилизација, таа полемизира со некои погледи на модерните критичари кои честопати ја интерпретираат грчката литература согласно

\section{Vesna Krstevska}

Towards Women in Greek Myth by Mary R. Lefkowitz, London: Bristol Classical Press,1995.

$T$ his impressive study by professor Lefkowitz is an attempt to describe how the Greek treated female experience in myths and to present some of the aspects of this experience that were regularly interpreted differently. Using a comparative method, Lefkowitz matches the myths with other Greek and Roman texts in order to approach the authentic language of the original text as close as possible. In addition, she avoids starting from a position of structural anthropology and discussing a complex issue using binary oppositions. The author no longer has the ambition to set this book aside for specialized readers - she can woo the reader with a simple, though analytical style, without pretensions for theoretical systematization.

In this study, Lefkowitz presents the female characters in myths, literature and historical documentation. She concentrates on those aspects of female experience that are most often misunderstood - life of wives separated from their husbands, marriage, women's role in politics, self-sacrifice and martyrdom and the nature of misogyny.

Attempting to discern the gender positioning in the story of Greek civilization, she polemizes with some modern critics' views. These critics oftentimes interpret Greek literature according to their standards and preoccupation, mostly read recounted 
со нивните стандарди и преокупации и најчесто ги читаат митовите во прераскажана форма и тргнуваат од критериумите кои важат за денешното општество, како и со феминистичката критика која честопати ги прифаќа овие критериуми и митот се сфаќа како рефлексија на светот во кој мажите доминираат над жените поради стравот од нивната сексуалност. Авторката настојува да прикаже дека не се работи за хиерархија и доминација на мажите („ако Грците сакале тоа да го потенцираат, би го кажале подиректно"- вели таа), затоа што страдањето и тагата се карактеристични воопшто за грчката религија. „Пораката" на митовите ги засега и двата рода бидејќи, кога се излегува од правилата на семејниот живот кој за Грците претставувал основа за космизираност на светот, тоа станува опасно за целото општество.

Сторијата на грчката митологија не ја раскажува несреќата на жената или репресијата од страна на мажите, туку тешките времиња на смртниците воопшто. Напротив, жената во грчкиот мит била образована (во Грција сите, вклучително и слободните луѓ и слугите, оделе во театар и ја познавале драмската поезија) и за разлика од претставата на жената во библиските текстови за која девственоста е врвниот идеал, жената во Грција поседува голем потенцијал за вклученост во јавната сфера на дејствување.

Видливоста и говорот за женската егзистенција започнува во периодот на нејзината иницијација во брачниот живот, и таа најчесто е запаметена по нејзината улога во семејството која е најпожелен модел за нејзина партиципација во општеството и најчесто оние кои имаат поинаква визија за својата примарна улога во животот се зли и деструктивни. Жените кои нешто постигнале се од аристократско потекло и најчесто се поврзани со некој значаен маж. Грчките писатели пишувале дека жените зборувале јавно за проблемите кои ги засегаат, но тие не донесувале одлуки. Тие биле храбри, но не биле вистински независни. Иако честопати се потенцира неконвенционалноста во однесувањето на некои антички жени, тоа се совпаѓa со она што се очекувало од нив во рамки на законите на семејството. Така Антигона ги брани семејните закони, Ифиге- myths and start from criteria that apply to society today. She also polemizes with feminist criticism, which often accepts those criteria and sees myth as reflections of a world where men dominate women because they fear their sexuality. The author insists on showing it is not a matter of hierarchy and domination ("had the Greeks wanted to stress that, they would have said it more directly" - she says), since suffering and sorrow are characteristic of Greek religion in general. The "message" of the myths is pertinent to both genders, for when the rules of family life (which is the basis for the cosmogenization of the world) are left behind, danger looms over entire society.

The story of Greek mythology is not about the unhappiness of women or their repression by men, but the hard time of mortals in general. On the contrary, women in Greek myths are educated (everybody in Greece, including free people went to theatre and knew the dramatic poetry) and as opposed to the concept of women in the Bible, where chastity is the primary ideal, the Greek woman has a great potential for admittance into the public sphere.

Visibility and mention of female existence appear in the period of her initiation in marital life and she is remembered mostly for her role in the family. This is the most favorable model of her participation in society and most of the time those with a different vision of their primary role in life are evil and destructive. Women who have achieved something have aristocratic background and are most often associated with an important husband. Greek writers wrote that women talked publicly about the problems that concerned them but did not participate in decision making. They were brave but not truly independent. Although the unconventional behavior of certain women in the ancient times is often emphasized, this complies with what was expected from them in the frames of the laws of family. Thus, Antigone defends the laws of the family, Ifigeny deceives the king in order to save her brother, Helen lies to save Menelaus - 
нија го мами кралот со цел да го спаси сопствениот брат, Елена зборува лаги за да го спаси Менелај, значи сите овие жени покажуваат еден облик на пасивен отпор и со ненасилни методи застануваат во одбрана на роднина од машки род. Лисистрата во истоимената драма на Аристофан се смета за прва либерална жена која прави договор за мир, но таа тоа го прави со цел зачувување и враќање кон семејството, што повторно зборува дека жените поседувале политички ставови и интелект, но не и независност. Интелигенцијата кај жените се потенцира, но за неа не било пожелно да прифати поразличен начин на живот, одвоен од мажот. Способноста на жената да се жртвува зборува и за нејзината храброст и одговорност пред општествените закони што ја изедначува со мажот. Конечно, жената ритуално постојано го космизира и хармонизира просторот околу себе.

Лефковиц ги анализира и текстовите на надгробните плочи, брачните договори, каталозите, историските текстови, бидејќи се покажало дека тие многу повеќе 3боруваат за статусот на жената и даваат поопиплива слика отколку митовите и литературните текстови. Таа прикажува некои сосема обични жени како што се жената филозоф Хипархија, која патувала со својот маж и ја ширела својата филозофија, Менофила која добивала почести од градот поради нејзиниот ум и поради нејзините лидерски способности, Хипатија-жена-филозоф која ги собирала кај себе највлијателните мажи.

Грчката жена ја живеела сопствената женственост. Родот не е главната причина за критиката која била упатувана кон жените кои биле видливи, неконвенционални и влијателни, туку причините пред се биле политички.

Иако во ова четиво авторката го остава отворено прашањето зошто можноста за вистинска независност на жената се чини туѓa на грчката мисла, таа ја прави видлива способноста на жената да размислува што иे било јавно признато од мажите. Лефковиц луцидно заклучува дека Агаменон во Орестија и во Одисеја не говори за прељубата на Клитемнестра, туку ја истакнува нејзината потреба за all these women show a sort of passive resistance and defend their male kin with nonviolent methods. Lystrate in Aristophanes' play with the same title is considered the first liberal woman to create a peace agreement, but she does that in order to save the family and return to it. Again, this speaks of the fact that women maintained political views and had intellect but did not have independence. Intelligence in women is emphasized but it was not becoming for them to adopt a different lifestyle, separated from the husband. Woman's ability to sacrifice speaks volumes about her courage and responsibility in the face of society laws and this equals her to men. Finally, the woman constantly cosmosizes and harmonizes the space around her in her rituals.

Lefkowitz analyzes everything from epitaphs, historical texts, catalogues to nuptial agreements because it has been proven that they say much more about the status of women and give a much more tangible view than myths and literary texts. She portrays some very ordinary women like the woman - philosopher Hyparchy who traveled with her husband and disseminated her philosophy, Menophila who received honors from the town for her wit and leadership abilities and Hypathia, the woman - philosopher who gathered the most influential men around herself.

The Greek woman lived her own femininity. Gender was not the principal reason for criticism directed towards the visible, unconventional and influential women - the reasons were primarily of a political nature.

Although the author leaves the question open on why the idea of true independence for women seems foreign to Greek thought, she renders women's ability to think (something publicly recognized by men) clearly visible. Lefkowitz lucidly concludes that in Orestia and Odyssey Agamemnon is not discussing Clytemnestra's adultery, but indicates her need for justice and ability to plan and think. After all, what 
правда и способноста да планира и размислува. Најпосле, она што ги плашело грчките мажи кај жената не е женската сексуалност, туку нивната интелигенција. men feared in women was not their sexuality, but their intelligence.

Translation: Sase Tasev 